\title{
38. BATHYMETRY AND OCEANIC CRUSTAL AGES IN THE VICINITY OF THE MOUTH OF THE GULF OF CALIFORNIA, ILLUSTRATED USING DEEP SEA DRILLING PROJECT LEG 63 UNDERWAY GEOPHYSICAL PROFILES ${ }^{1}$
}

\author{
Gordon E. Ness and Osvaldo Sanchez Z., School of Oceanography, Oregon State University, Corvallis, Oregon, \\ and Instituto Oceanográfico, Manzanillo, Colima \\ Richard W. Couch, School of Oceanography, Oregon State University, Corvallis, Oregon \\ and \\ Robert S. Yeats, Department of Geology, Oregon State University, Corvallis, Oregon
}

\begin{abstract}
We used recently acquired and rigorously navigated underway geophysical data from the region of the mouth of the Gulf of California to prepare detailed bathymetric and crustal age maps along a swath approximately $200 \mathrm{~km}$ wide paralleling DSDP Leg 63 track lines between Sites 471, 472, and 473. The basement ages of the drilling sites, estimated from magnetic anomalies fit to time scale NLC-80, are 15.5 m.y., $15.2 \mathrm{~m} . \mathrm{y}$., and $6.5 \mathrm{~m} . \mathrm{y}$., respectively. These estimates are in agreement with biostratigraphically determined basement ages and support the proposal that an aborted ridge of about $13.7 \mathrm{~m}$.y. of age has left a small fragment of the Farallon plate beneath the Magdalena Fan at $23.5^{\circ} \mathrm{N}, 112.5^{\circ} \mathrm{W}$. In addition, we identify four large faults in the region, each of which is about $200 \mathrm{~km}$ long, and several minor faults. In particular, the region southwest of Cabo San Lázaro and west of Cabo San Lucas is complexly faulted.

Our results contradict the recently proposed existence of a 3.5-m.y.-old aborted spreading center west of the Tres Marias Islands. Alternatively, subduction of the Pacific plate beneath the southeastern tip of Baja California and concomitant strike-slip faulting west of the peninsula may be responsible for the uncentered location of the Rivera Ridge in the mouth of the Gulf of California.
\end{abstract}

\section{THE DATA BASE}

Since 1975 researchers of the School of Oceanography at Oregon State University (OSU) and of the Dirección General de Oceanografía (DGO), an agency of the Mexican Secretaria de Marina, have participated in a cooperative marine geophysical research program intended to construct a reconnaissance-scale geophysical atlas of the Pacific economic zone of Mexico. Toward this end, four survey cruises have been conducted using vessels of the Mexican Navy to obtain underway bathymetric, gravimetric, and magnetic data. Because of the rigorous navigational requirements inherent in measuring gravity at sea, and because useful LORAN-C coverage does not exist off the Pacific coast of Mexico, the cruises were designed as "steaming cruises." Few station data were collected; track lines were laid out to be long and straight in order to maximize the number of satellite fixes along track and to minimize the number of Eötvös discontinuities introduced into observed gravity with course and speed changes.

We merged all the OSU/DGO project data with the considerable volume of geophysical data previously acquired off Mexico by research vessels of Oregon State University. The whole was iteratively renavigated to minimize track-line crossing errors while we paid particular attention to calculated versus observed Eötvös discontinuities. By repeated calculation and comparison, a tedious process that in effect treats the shipboard

\footnotetext{
${ }^{1}$ Initial Reports of the Deep Sea Drilling Project, Volume 63.
}

gravimeter as an inertial navigation instrument, a large, internally consistent set of well-navigated geophysical survey track-lines of the Pacific margin of Mexico has been generated. Tracks in the subject area of this report are in the inset to Figure 1 (back pocket, this volume).

These data and additional data of comparable accuracy (obtained from the National Geophysical and Solar-Terrestrial Data Center and the Defense Mapping Agency) were used to construct a set of marine geophysical maps of the region west of Baja California that has recently been published (Calderon R. and Couch, 1980). Values for the root-mean-square of the crossing errors for the free-air gravity anomaly maps of this region ranged from 2.0 to $4.6 \mathrm{mgal}\left(2.0\right.$ to $\left.4.6 \times 10^{-5} \mathrm{~m} / \mathrm{s}^{2}\right)$, with an estimated overall positional accuracy of $2 \mathrm{~km}$. In this study we use part of the same high-quality data set along with DSDP Leg 63 bathymetric, magnetic, and single-channel seismic reflection profiles between Sites 471,472 , and 473 to construct two maps of the region near the mouth of the Gulf of California.

A bathymetric map (Figure 1) contoured at a 200 meter interval was constructed using, in addition to the data discussed above, other recently published maps of parts of the region as underlays. These include maps of the Rivera Fracture Zone and vicinity by Mammerickx et al. (1978), the Gulf of California proper by Bischoff and Niemitz (1980), and the Tamayo Fracture Zone as mapped by Lewis et al. (1979). We also used certain renavigated bathymetric profiles for the region west of Baja California provided by William Normark of the U.S. Geological Survey (Spencer and Normark, 1980). Line drawings of Leg 63 single-channel seismic reflection profiles are included as part of Figure 1. 
We constructed an oceanic crustal isochron map (Fig. 2 , back pocket, this volume) indicating the age of the deep seafloor in millions of years (m.y.). The isochrons were interpreted from marine magnetic anomaly profiles as fitted to time scale NLC-80 (Ness et al., 1980). The map was compiled from OSU/DGO project data and DSDP Leg 63 profiles. Additional magnetic anomaly profiles from other sources were examined, in particular the profiles west of Baja California illustrated by Chase et al. (1970), when our own project data were inadequate or lacking. We made no attempt to renavigate magnetic data from other sources or to integrate them with our files, because the bulk of the available information was obtained on cruises conducted prior to the advent of nonmilitary satellite navigation systems and gravity data were not obtained during those cruises.

In summary, the two maps compiled for this report are based primarily on our own data set; we are reasonably confident of the navigational accuracy of these data. The maps cover a swath extending approximately 100 $\mathrm{km}$ to either side of the DSDP Leg 63 track-lines connecting Sites 471, 472, and 473; they were designed specifically to provide physiographic and tectonic background information pertinent to Leg 63 objectives. An interpretation of the tectonic history of the mouth of the Gulf of California region, based upon Leg 63 results, is presented elsewhere (Yeats and Haq, this volume). The first three authors of this chapter are presently preparing a more extensive discussion of the tectonic history of the central portion of the Pacific margin of Mexico on the basis of the OSU/DGO project data.

\section{BATHYMETRY AT THE MOUTH OF THE GULF}

For clarity and economy we refer to that section of the East Pacific Rise located between the Rivera and Tamayo fracture zones as the Rivera Ridge, and that portion of the Middle America Trench north of the Rivera Fracture Zone as the Rivera Trench. We name the thick fan of sediments found at the base of the continental slope, southwest of Magdalena Bay, the Magdalena Fan. DSDP Site 471 is located on this feature (Fig. 1, map and section). The fan extends westward from the slope base at 3000 meters depth to a swale marked by the 3600 -meter contour just south and east of a prominent seamount located near $23.4^{\circ} \mathrm{N}, 113.3^{\circ} \mathrm{W}$. A single-channel seismic reflection profile, here labeled DSDP-63N, indicates that the western edge of the fan, or the eastern side of the swale, is marked by a small basement high. The fan extends to the north as far as $24.2^{\circ} \mathrm{N}, 112.7^{\circ} \mathrm{W}$, and to the south as far as $23.3^{\circ} \mathrm{N}$, $111.8^{\circ} \mathrm{W}$. Bathymetrically it appears to be fault-bounded at both sides. The seismic reflection profile DSDP-63N indicates that the fan is more than $1.75 \mathrm{~s}$ thick near the slope base where oceanic basement dips toward the northeast beneath Baja California. A pronounced freeair gravity anomaly minimum extends along the base of the continental slope west of the peninsula (Huehn, 1977; Coperude, 1978; Calderon R., 1979; Calderon R. and Couch, 1980). It is contiguous with the Cedros Trough far to the northwest. In the region south of Cabo San Lázaro, it apparently marks the sediment- covered extension of that feature in the subsurface, which is generally interpreted to be a fossil subduction zone. Near $23^{\circ} \mathrm{N}, 111^{\circ} \mathrm{W}$, the axis of this minimum (labeled as the approximate base of the continental slope in Fig. 2) forms a small cusp where several pronounced gravimetric lineations meet. This trough, and presumably the thick wedge of sediments masking it, extends to the south and east of Cabo San Lucas at the tip of the peninsula.

The physiography of the deep seafloor west of the continental slope of the peninsula is quite complicated. At least four small depressions deeper than 4000 meters exist in the region. One, near $24^{\circ} \mathrm{N}, 114.3^{\circ} \mathrm{W}$, appears in map view to be fault-bounded and is more than 4400 meters deep. We can recognize no dominant bathymetric trend in the region north of $23^{\circ} \mathrm{N}$ and west of $113^{\circ} \mathrm{W}$. However, bathymetry and discontinuities in the crustal isochrons allow us to identify at least one probable fault, here called the San Lázaro Fracture Zone. In general, the major structural characteristics of this particular area are of a scale finer than our track-line separation. However, two other significant features may be recognized in the bathymetry of the region west of Cabo San Lucas.

First, a well-defined trough extends toward the northeast from $22^{\circ} \mathrm{N}, 113.5^{\circ} \mathrm{W}$ and meets the slope base at $23.3^{\circ} \mathrm{N}, 111.7^{\circ} \mathrm{W}$. It is noteworthy that this feature, here called the Ulloa Fracture Zone, meets the peninsula at a point where the character of the continental shelf and slope abruptly changes. Several linear bathymetric features are truncated along a line extending onto peninsular crust from the Ulloa Fracture Zone, but this may be coincidental.

Second, an unusual bathymetric high is located near $22.8^{\circ} \mathrm{N}, 112.8^{\circ} \mathrm{W}$. In map view it is triangular in outline, bounded to the southeast by the Ulloa Fracture Zone, to the southwest by a bathymetric gradient that also appears to offset the magnetic anomaly pattern near $22.8^{\circ} \mathrm{N}, 113.5^{\circ} \mathrm{W}$, and to the northeast by a long trough about 3600 meters deep marking the distal part of the Magdalena Fan. Thus it appears to be faultbounded on at least two, and perhaps all three, sides. In profile view (Fig. 1 section) the feature is unusual in appearance. It is distinct from typical seamount profiles, such as the one located farther east along the same section. The feature is approximately $50 \mathrm{~km}$ wide along this DSDP track and exhibits about 1000 meters of relief. It looks more like a ridge crest in profile than does the actual Rivera Ridge, which is located farther east.

East of $110^{\circ} \mathrm{W}$, the linear ridge and trough province of the actively spreading Rivera Ridge trends toward the north-northeast and generally lies above 3000 meters depth. It is not possible to locate the precise spreading axis from bathymetry data alone or, for that matter, from magnetic anomalies with or without bathymetry. Two fairly deep troughs, both relatively free of sediment fill, occur near the ridge axis. Both, however, are discontinuous along the trend of the ridge, and the approximate middle of the central magnetic anomaly is located east of the two troughs. The situation is additionally confused because the DSDP profile (Fig. 2) 
crosses the ridge very near where we propose a small left offset in the spreading axis. From the ridge area to Site 473, the DSDP Leg 63 track runs parallel and very near to a fracture zone trending northwest from $21^{\circ} \mathrm{N}$, $107^{\circ} \mathrm{W}$. This feature, named Fracture Zone W by Mammerickx (1980) and here called the Esplandian Fracture Zone, is very well defined bathymetrically as far west as about $107.7^{\circ} \mathrm{W}$, where the Leg 63 profile may actually cross it. We believe that the fracture zone extends to the ridge crest at $22^{\circ} \mathrm{N}$, on the basis of seismic activity and offsets in magnetic anomalies (to be discussed later). This fault also appears to extend across the Rivera Trench into continental crust at the slope base just west of Cabo Corrientes.

The DSDP-63S profile (Fig. 1 section) illustrates a broad, gentle rise in acoustic basement immediately southwest of Cabo San Lucas that seems to be related to the presence of the peninsula. This rise lies seaward of the gravitational trough previously discussed and may represent an outer trench high caused by flexure of the lithosphere. If so, the profile would be tangent to the high that bends around the tip of the peninsula. In any case, the feature is not a sediment fan, as it might appear in map view.

Just east of the high, there is a small depression in the bathymetry that is parallel to the trend of the ridge and trough province. The seismic reflection profile shows it to be adjacent to a pronounced sediment-filled basement low. On the basis of offsets in the magnetic anomalies (to be discussed in the next section) we consider this basin to be part of a long, east-trending fault, here called the Calafia Fracture Zone.

Finally, seismic activity and offsets in both bathymetry and magnetics aid us in recognizing a second left offset in the Rivera Ridge, here called the Montalvo Fracture Zone, located at $21.2^{\circ} \mathrm{N}, 108.9^{\circ} \mathrm{W}$.

In summary, the bathymetry of the region west of southern Baja California is complicated. By limiting our data set only to that information we consider to be reliably located, we have sacrificed some resolution, but we are confident that our interpretation is at least not overly affected by faulty navigation. To some extent, analysis of the magnetic anomalies will enable us to better define the location and orientation of certain faults immediately west of the peninsula. Two major faults in the study area are quite visible from the bathymetry alone. These are the Ulloa and Esplandian fracture zones, both of which may extend into the continental crust.

\section{OCEANIC CRUSTAL ISOCHRONS AT THE MOUTH OF THE GULF}

Total magnetic field anomalies were determined by application of the 1975 International Geomagnetic Reference Field to values measured along the track lines indicated in Figure 1. These were then compared with synthetic magnetic anomaly profiles generated using the method of Talwani and Heirtzler (1964). Marine magnetic anomaly time scale NLC-80 (Ness et al., 1980) was used as a time base. The synthetic anomaly profile illustrated at the bottom of Figure 2 is similar to that which would be measured at the sea surface, over 3000 meters of water, with magnetic source bodies of 500 meters thickness, an assumed half-spreading rate of 30 $\mathrm{km} / \mathrm{m} . \mathrm{y}$. at the Rivera Ridge, and a ridge trend of $25^{\circ}$. The asymmetry of the calculated anomalies, caused by the $25^{\circ}$ departure of the spreading ridge from a northsouth orientation, requires an adjustment in assigned ages depending upon whether peaks are located east or west of the ridge crest. These ages were proportioned from the NLC-80 time base, and the observed anomalies (along the tracks illustrated in the inset to Figure 1) were assigned ages to tenths of millions of years. DSDP Leg 63 magnetic anomaly profiles DSDP-63N and $-63 \mathrm{~S}$ are illustrated in Figure 2 and show the age assignments we made to them. The crustal isochron map is the result of all such correlations made to the observed magnetic anomaly profiles in the study area.

The axis of the Rivera Ridge as indicated in Figure 2 was located by interpolation to zero age between the youngest isochrons on either side of the ridge. Because of the possibility of spreading asymmetries younger than 0.7 m.y., the actual axis of divergence may be located slightly differently than we specify here.

The profiles from earlier studies of the magnetics of the Rivera Ridge area (e.g., Larson, 1972) and later studies that used the same data set (e.g., Mammerickx, 1980) were not integrated into this work, because we lack confidence in their navigational accuracy. West of southern Baja California, and in particular west of $114^{\circ} \mathrm{W}$, however, our OSU/DGO project data were insufficient, and so we examined older profiles illustrated in Chase et al. (1970) to try to determine crustal ages seaward of DSDP Site 472.

The crustal isochrons on the Pacific flank of the Rivera Ridge appear to have been parallel to the ridge back to at least $2.0 \mathrm{~m} . \mathrm{y}$. ago. Progressively older isochrons on the Pacific plate appear to have fanned anticlockwise very slightly between $2 \mathrm{~m}$.y. and $6.5 \mathrm{~m} . \mathrm{y}$. ago, and more strongly between $6.5 \mathrm{~m} . \mathrm{y}$. and $9 \mathrm{~m} . \mathrm{y}$. ago. On the Rivera plate south of the Esplandian Fracture Zone, the same anticlockwise fanning of isochrons appears to have begun $2.5 \mathrm{~m} . \mathrm{y}$. ago, and by $7.3 \mathrm{~m} . \mathrm{y}$. ago the oldest identifiable positive anomaly was oriented almost north-south. On the Pacific side this due north-south orientation occurred about 9 m.y. ago. North of the Esplandian Fracture Zone, the isochrons were approximately parallel to the ridge back to 5.3 m.y. ago except very near the fracture zone itself. We estimate the basement age of DSDP Site 473 to be about $6.5 \mathrm{~m} . \mathrm{y}$. from the isochron map and the DSDP-63S profile correlation (Fig. 2).

We interpret progressively older anomalies back to at least $5.3 \mathrm{~m}$.y. ago in the section of the Rivera plate north of the Esplandian Fracture Zone. This disagrees with the findings of Mammerickx (1980), who proposed the existence of an aborted $3.5 \mathrm{~m} . \mathrm{y}$. spreading center on the topographic high due west of the Tres Marias Islands at $21.5^{\circ} \mathrm{N}, 107^{\circ} \mathrm{W}$. This feature, named the Maria Magdalena Rise by Mammerickx, is bounded approximately by the 3000-meter-depth contour. Our bathymetry, which differs slightly from that of Mammerickx, shows 
a narrow high (at 2600 meters depth) located at $22^{\circ} \mathrm{N}$, $107.5^{\circ} \mathrm{W}$ (Fig. 1). This feature could constitute physiographic evidence in support of her proposed ridge, however, our interpretation of the magnetic anomalies is that this feature is on crust 3.8 to $4.0 \mathrm{~m}$.y. old, with progressively older anomalies to the east. Furthermore, the 2600 -meter bathymetric high is located on the western edge of the Maria Magdalena Rise, which contradicts the age-depth relationship required by the aborted ridge model of Mammerickx.

Similarly, our interpretation of the magnetic anomalies of the study area does not support the existence of Fracture Zone X of Mammerickx. Her Fracture Zone Y similarly has no definite magnetic expression, but does appear bathymetrically to be in line with the left-offset Montalvo Fracture Zone, which we show at the Rivera Ridge on the basis of magnetic and bathymetric offsets and in particular on the basis of recurrent seismic activity.

If our interpretation of the magnetic anomalies near the Esplandian Fracture Zone is correct, then an unusual tectonic history is indicated in the crustal isochron pattern. Note that the fracture zone shows no offset from 1.0 to $2.4 \mathrm{~m}$.y. ago, that it appears to be right-offset from 2.4 to perhaps $4.7 \mathrm{~m}$.y. ago, and that it may be left-offset beyond 4.7 m.y. ago, depending upon the reality of the kinks in the isochrons at 4.7, 5.3, 5.6 , and 6.0 m.y. ago. The fracture zone may have multiple traces near $107^{\circ} \mathrm{W}$. At the western end of the fracture zone, we propose a small left offset of the Rivera Ridge younger than $1 \mathrm{~m} . \mathrm{y}$. Note also that the fracture zone does not have bathymetric expression west of the ridge. All of this implies a complicated spreading history, possibly involving several periods of asymmetrical spreading, and also probably requiring the past existence of an independent northern segment of the Rivera plate.

If we are correct in denying the presence of an aborted ridge west of the Tres Marias Islands, then the asymmetrical location of the Rivera Ridge and the contrast in oldest anomaly ages on either side of the gulf seem to require that crust older than $3.5 \mathrm{~m}$.y. was subducted northwestward beneath the southeastern tip of Baja California, as proposed by Huehn and Couch (1976). This is, of course, kinematically possible, provided that at least the southernmost portion of Baja California be decoupled from the Pacific plate during the time of subduction. This in turn would imply right lateral strike-slip motion along the west side of the peninsula, similar to that proposed by Spencer and Normark (1980).

Finally, the anticlockwise fanning of anomalies with distance from the ridge found on both the Pacific and Rivera plates indicates that the Rivera Ridge began rotating clockwise, acting independently of the East Pacific Rise, at approximately the young boundary age of Anomaly 5 ( $\sim 9$ m.y. ago) as proposed earlier by Ness and Lynn (1975).

South and west of southern Baja California, the pattern of isochrons is very complicated. The observed magnetic anomalies along profile DSDP-63S show a repetition of Anomaly 3 immediately south of Cabo San Lucas. Anomaly $3^{\prime}$ is difficult to identify farther west, but the correlations of Anomalies 4, 4', and 5 are convincing. Apparent spreading half rates measured along this profile (Fig. 2 inset) increase at about 5 m.y. from 28 to $36 \mathrm{~km} / \mathrm{m}$.y. We identify this offset as the eastern end of what is here called the Calafia Fracture Zone. A series of isochron offsets older than 5 m.y. extend this feature to the west as far as $112.5^{\circ} \mathrm{W}$, and differences in isochron orientation extend it farther west to about $113.3^{\circ} \mathrm{W}$. It has very little bathymetric expression but may bound the northern flank of a topographic high near $22^{\circ} \mathrm{N}, 111.5^{\circ} \mathrm{W}$. This feature is in turn bounded to the south by an unnamed fracture zone older than 6.5 m.y. trending east-southeast as defined by isochron offsets.

Farther west along the DSDP-63S profile, a slight change in apparent spreading half rate occurs at the Ulloa Fracture Zone. We can only convincingly identify the 10.9-m.y. isochron across the length of the fracture zone. Other profiles provide no help. But, if our $10.9-\mathrm{m} . \mathrm{y}$. correlation is correct, it is noteworthy that there is very little offset in isochrons across the Ulloa Fracture Zone, despite the fact that it has pronounced bathymetric definition.

Another isochron offset is observed at about 13 m.y. along the DSDP-63S profile. We have no additional magnetic evidence to help define its orientation. A bathymetric gradient trends in the direction indicated and intersects the Ulloa Fracture Zone at $113^{\circ} \mathrm{W}$ where that feature has a slight change in trend.

The western end of profile DSDP-63S is characterized by anomalies that are similar to the synthetic anomalies from 14 to $15 \mathrm{~m} . \mathrm{y}$. This similarity is certainly not ideal, but the interpretation made is consistent with the rest of the profile. We attempted to use the profiles illustrated in Chase et al. (1970) to help confirm our correlation, but found that the anomalies shown were very difficult to identify by comparison with synthetic anomalies. The dot-dash lines on Figure 2 mark the positive peaks of anomalies that we could recognize as continuous between profiles. We could not project them north of $22.5^{\circ} \mathrm{N}$ or south of $23^{\circ} \mathrm{N}$ with confidence. Therefore our estimate of $15.2 \mathrm{~m}$.y. for the crustal age at DSDP Site 472 is made exclusively on the basis of our own data. It is, however, in agreement with the anomaly identifications made by Chase et al. (1970).

One possible explanation for our inability to identify the anomalies shown by Chase et al. is that the time scale (NLC-80) used in this study incorporates the North Pacific, Anomaly 4 to Anomaly 6 time scale of Blakely (1974). This postdates the time scale used in Chase et al. Assuming that the Blakely time scale is accurate, and we do, then the anomalies west of $\sim 114^{\circ} \mathrm{W}$ in this study are either of a radically different age than that given by Chase et al. or are a product of nonconstant spreading. Lacking more detailed survey track lines, we can only pose the problem.

Profile DSDP-63N connects Sites 471 and 472 . We emphasize the very good correlation between the $63 \mathrm{~N}$ and $63 \mathrm{~S}$ profiles from 14 to $15 \mathrm{~m} . \mathrm{y}$. However, the 
eastern half of DSDP-63N is difficult to correlate with synthetic anomalies. Paleontological evidence presented elsewhere in this volume indicates that the basement ages of Sites 471 and 472 are similar, implying either a large fault offset somewhere between the sites or an aborted ridge located midway between them. Both possibilities seemed unlikely to the first three authors of this report when they read the Leg 63 onboard results article (Haq et al., 1979). It seemed more likely that the problem posed by the similar dates was due to difficulties in the biostratigraphy. We tried to fit profile DSDP-63N to DSDP-63S, and to constant spreading synthetic anomaly profiles, but kept coming back to the mirror symmetry of DSDP-63N about its midpoint. The eastern half of that profile certainly does not fit corresponding points in Profile DSDP-63S. The most reasonable conclusion that we could reach is that Site 471 basement is indeed as old or slightly older than Site 472 basement, and we here estimate its age at $15.5 \mathrm{~m} . \mathrm{y}$.

This is not a completely satisfying conclusion, because it requires the rather ad hoc presence of a fault trending approximately east from $23.3^{\circ} \mathrm{N}, 113.1^{\circ} \mathrm{W}$. It is possible that the swale marking the distal part of the Magdalena Fan is fault-controlled, as previously discussed. In this case the topographic high near $23^{\circ} \mathrm{N}$, $113^{\circ} \mathrm{W}$ would be fault-bounded on all three sides. In our isochron map we indicate that this fault terminates at the aborted spreading center, here named the Magdalena Ridge. We estimate the age of the ridge to be about $13.7 \mathrm{~m} . \mathrm{y}$., if it exists. The fault probably continues west of the ridge, but we are unable to determine its orientation.

\section{ACKNOWLEDGMENTS}

We thank Bob Duncan and Mitch Lyle for reviewing this manuscript. Bill Normark provided helpful bathymetric data for the shelf and slope west of Baja California. Jacqueline Mammerickx sent a preprint of her 1980 paper on the mouth of the Gulf of California. Mike Gemperle, Gerry Connard, and particularly Jeb Bowers have participated in very nearly every aspect of the OSU/DGO Mexico geophysics project. They are, as always, good sailors, valuable colleagues, and great shipmates. We also thank the officers and crews of the Mexican Navy research vessels D-20 and Mariano Matamoros for their assistance on our survey cruises. And we thank Gustavo Calderon R. for helping to make the OSU/DGO project possible. This report was supported, in part, by the Office of Naval Research Contract N00014-67-A-0007 under Project NR 083-102.

\section{REFERENCES}

Bischoff, J. L., and Niemitz, J. M., 1980. Bathymetric maps of the Gulf of California, USGS Misc. Investig. Series Map I-1244.

Blakely, R. J., 1974. Geomagnetic reversals and crustal spreading rates during the Miocene. J. Geophys. Res., 79:2979-2985.

Calderon R., G., 1979. A marine geophysical study of Vizcaino Bay and the continental margin of western Mexico between $27^{\circ}$ and $30^{\circ} \mathrm{N}$ latitude [Ph.D. thesis]. Oregon State University.

Calderon R., G., and Couch, R. W., 1980. Atlas geofisico de la margen continental oeste Mexico, $22^{\circ}-33^{\circ} \mathrm{N}$, Sección I, Dirección General de Oceanografia, Mexico, D.F.

Chase, C. G., Menard, H. W., Larson, R. L., et al., 1970. History of sea-floor spreading west of Baja California. Bull. Geol. Soc. Am., $81: 491-498$.

Coperude, S., 1978. Geologic structure of the western continental margin of south central Baja California based on seismic and potential field data [M.S. thesis]. Oregon State University.

Haq, B., Yeats, R. S., et al., 1979. Eastern Pacific boundary currents. Geotimes, 24:30-31.

Huehn, B., 1977. Crustal structure of the Baja peninsula between latitudes $22^{\circ} \mathrm{N}$ and $25^{\circ} \mathrm{N}$ [M.S. thesis]. Oregon State University.

Huehn, B., and Couch, R. W., 1976. Crustal structure of Baja and the Gulf of California between latitudes $22^{\circ} \mathrm{N}$ and $25^{\circ} \mathrm{N}$. EOS, Trans. Am. Geophys. Union, 57:932.

Larson, R. L., 1972. Bathymetry, magnetic anomalies and plate tectonics history of the mouth of the Gulf of California. Bull. Geol. Soc. Am., 83:3345-3360.

Lewis, B. T. R., Robinson, P., et al., 1979. Leg 65 drills into young ocean crust. Geotimes, 24:16-18.

Mammerickx, J., 1980. Neogene reorganization of spreading between the Tamayo and the Rivera fracture zones. Mar. Geophys. Res., 4:305-318.

Mammerickx, J., Reichle, M. S., and Reid, I. D., 1978. Bathymetry of the Rivera Fracture Zone, Scripps Inst. Oceanogr. IMR Tech. Rep. Ser. TR-62.

Ness, G. E., Levi, S., and Couch, R. W., 1980. Marine magnetic anomaly timescales for the Cenozoic and late Cretaceous-a precis, critique and synthesis. Rev. Geophys. Space Phys., 18: 753-770.

Ness, G. E., and Lynn, W., 1975. Rivera revisited: confusing motion beneath the ocean. Geol. Soc. Am. Program with Abstracts, Cordilleran Section Meeting, 7(3).

Ness, G. E., Sanchez Z., O., Couch, R. W., et al., in preparation. Late Neogene tectonics of the mouth of the Gulf of California.

Spencer, J. E., and Normark, W. R., 1980. Tosco-Abreojos fault zone: a Neogene transform plate boundary within the Pacific margin of southern Baja California, Mexico. Geology, 7:554-557.

Talwani, M., and Heirtzler, J. R., 1964. Computation of magnetic anomalies caused by two-dimensional structures of arbitrary shapes. In Computers in the Mineral Industries (Vol. 9): Stanford, Ca. (Stanford University Publications), 464-480. 